\title{
Optimisation of Front Metallisation Pattern in Silicon Solar Cells for Annual Energy Yield
}

\author{
Miha Kikelj, Benjamin Lipovšek, Marko Topič \\ University of Ljubljana, Faculty of Electrical Engineering, Ljubljana, Slovenia
}

\begin{abstract}
With photovoltaic installations reaching into the 1 TWp range and the demand for green electric energy on the rise, every fraction of a percent of increased solar cell efficiency counts, and would result in a substantial increase in the annual energy yield of the installed photovoltaic capacities. An optimisation of the front metallic grid would provide a relatively simple yet cost-effective boost to the solar cell efficiency. We employed a freely available 2.5D photovoltaic simulator to model shading and resistive losses of the front metallisation grid, and for further optimisation of the grid for annual energy yield regarding the irradiation distribution. We were, therefore, able to increase the effective efficiency of the simulated solar cells up to $1 \%$ over the whole year depending on the location.
\end{abstract}

Keywords: Energy yield optimisation; Metallisation grid optimisation; PVMOS

\section{Optimizacija sprednje metalizacïje silicijevih sončnih celic na nivoju letnega donosa energije}

\begin{abstract}
Izvleček: Maksimalna skupna inštalirana vršna moč sončnih elektrarn je začela posegati v 1 TWp območje, popraševanje po čisti električni energiji pa je vedno večje, zato je dobrodošlo tudi najmanjše povečanje izkoristka sončnih celic, ki pa bi, zaradi masovne uporabe, izdatno pripomoglo k letnem izplenu energije sončnih elektrarn. Optimizacija prednje metalizacije predstavlja enostavno in poceni možnost povečanja izkoristka sončnih celic. Z uporabo 2.5D fotovotaičnega simulatorja smo modelirali izgube zaradi upornosti in senčenja prednje metalizacije in optimizirali prednjo metalizacijo za čimvečji letni izplen energije. Na tak način nam je uspelo povečati efektivni izkoristek modeliranih celic za do $1 \%$ v celem letu, odvisno od modelirane lokacije.
\end{abstract}

Ključne besede: Optimizacija energijskega izplena, Optimizacija prednje metalizacije, PVMOS

*Corresponding Author's e-mail: miha.kikelj@fe.uni-lj.si

\section{Introduction}

A booming market for photovoltaics (PV) has exceeded 400 GWp [1] of installed PV capacity in 2017 and the prognosis shows that it is to reach as much as $1 \mathrm{TWp}$ of installed PV capacity by 2022/23 [2]. Operation at terawatt-scales gives us the ability to vastly increase the global energy production with even the smallest increase in the performance of each individual solar cell. As PV technologies are spreading to every corner of the globe, an idea of optimising solar cells to their expected operating conditions instead of standard test conditions (STC), has arisen, maximising their annual energy yield instead of promoting performance at STC, since they hardly ever occur during field operation. Since Silicon wafer based PV technologies still take up the majority of the global market [1], an optimisation of screen printed front metallisation of top contacted silicon solar cells, could lead to a vast energy yield increase with virtually no additional production costs [3].

Optimisation of front metallic grids can be approached analytically as performed by A. R. Burgers [4], and then applied to a STC or energy yield optimisation as performed by A.R. Burgers et al. [3]. But in order to be able to accurately evaluate the effects of more complex front metallisation grids, to optimise them and to optimise them with respect to arbitrary operating conditions and annual energy yield, more elaborate numerical tools need to be employed.

In our contribution we evaluate the use of PhotoVoltaic Module Simulator (PVMOS) [5] as a tool to accurately 
simulate the effects of front metallisation shading and resistive losses on the maximum power point of a silicon solar cell. On that basis we will further optimise the metallisation grid at different irradiation levels, and finally try to estimate the impact on the annual energy yield. With that knowledge we will undertake the challenge of optimising a solar cell metallisation according to yearly irradiation distributions at different locations and assess the impact on estimated annual energy yield compared to STC cell optimisation.

\section{Modelling}

PhotoVoltaic Module Simulator (PVMOS) developed by Bart Pieters [5] is a 2.5D quasi-SPICE simulator designed to efficiently simulate photovoltaic devices. It allows for creation of an accurate device model in two dimensions and the third dimension is simulated by stacking and interconnecting 2D layers. Sheet resistances are defined for each layer, or more accurately each segment of a layer, allowing for simulation of patterned structures. The connection between planar patterned layers could either be resistive, a p-n junction (described by a one or two-diode model) or it could implement an arbitrary J-V characteristic. A simplified part of a 4-layer (ribbon, front metallisation, emitter, and bulk with bottom metallisation) silicon solar cell model could therefore be represented as shown in Fig. 1 , where vertical resistive connections are omitted for simplicity. A detailed explanation of the PVMOS simulator is available in [6].

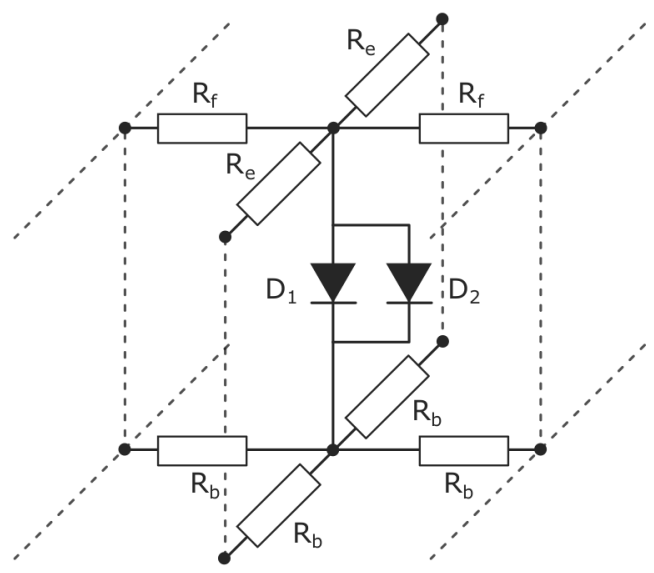

Figure 1: Simplified PVMOS model of a small section of a 3D cell

After the simulation nodal voltages and currents along all three axes become available along with the cumulative $I-V$ characteristic, which allows for evaluation of the simulated structure on the device level as well as on a local, more detailed level. In this work PVMOS will be used as a tool to model shading and resistive losses of the front metallisation pattern.

We built a set of MATLAB scripts and tools around the PVMOS simulator allowing for automatic geometry generation, geometry and solar cell parameter sweeps, and energy yield estimation, since a normal simulation procedure would require more than 10 individual manual steps.

\section{Results and discussion}

\subsection{Analysis of front metallisation losses}

According to literature [7] losses associated with the front metallisation can be divided into two categories, namely shading and resistive losses, whose individual effects on the $I-V$ curve are depicted in Fig. 2. One can see that shading losses mainly affect the short circuit current, while resistive losses decrease the fill-factor of the cell. In the following subchapters fractional power losses of individual origin will be evaluated through PVMOS simulations and the trends will be compared to analytical expressions from previous work. All symbols used are defined in the Appendix.

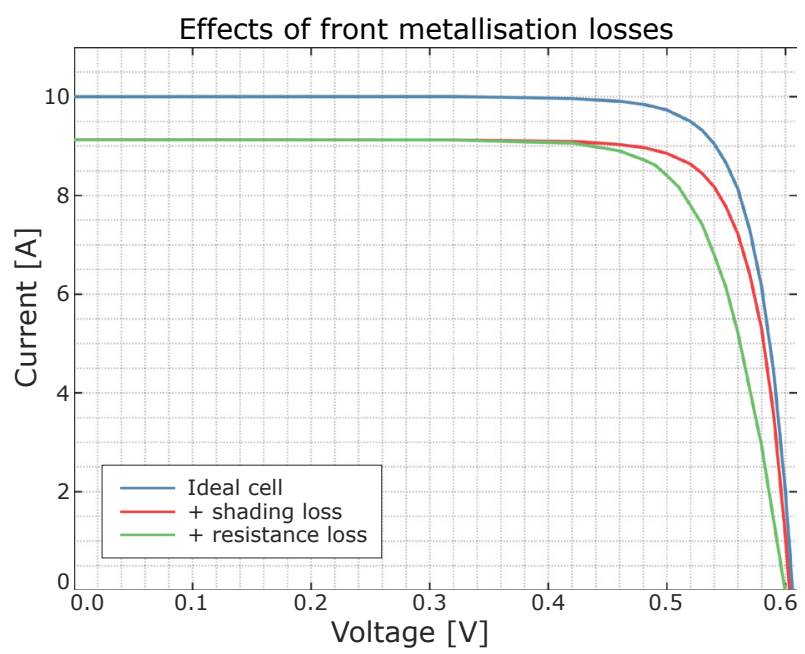

Figure 2: Effects of shading and resistive losses on an I-V curve.

\subsubsection{Fractional power loss}

Since different cell configurations are evaluated, producing a variety of power-voltage curves and therefore different maximum power points (MPP), it is necessary to employ a measure of power loss that is comparable between configurations. The measure - fractional power loss $p$ [7] is defined as the ratio between lost power $P_{\text {loss }}$ and power in the MPP $P_{\text {MPP }}$ of an ideal, unshaded cell as shown in equation (1). 
$p=\frac{P_{\text {loss }}}{P_{M P P}}=\frac{P_{\text {ideal }}-P_{\text {lossy }}}{P_{M P P}}$

\subsubsection{Shading losses}

Cell's self-shading losses are mainly caused by direct finger and busbar shading and are generally linearly proportional to the area of the shading elements.

\section{Busbars}

From definition [7] busbar shading losses $p_{s b}$ are proportional to the ratio of the busbar width $W_{B}$ and the spacing between them $B$, as it is evident from equation (2). Fig. 3 shows shading loss obtained by PVMOS simulations and as one would expect it exhibits a linear relation.

$p_{s b}=\frac{W_{B}}{B}=2 \frac{W_{B} N_{B}}{W_{C}} \propto W_{B} N_{B}$

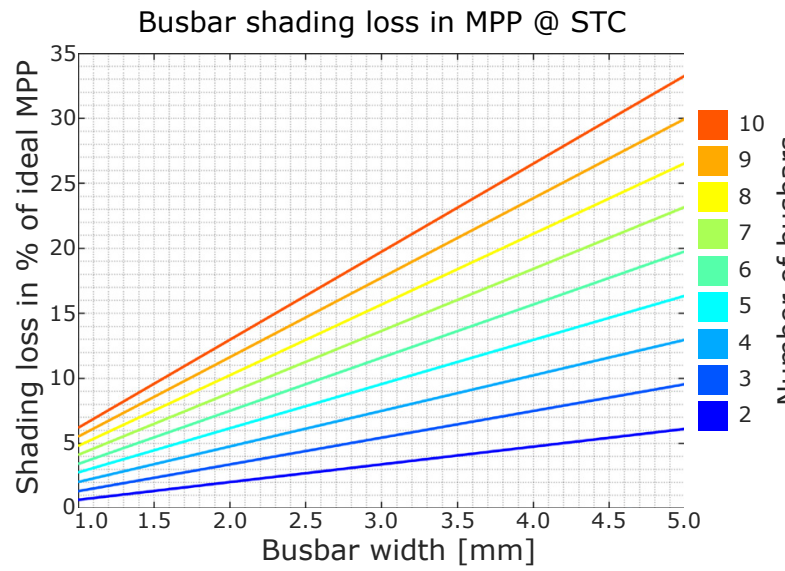

Figure 3: Busbar shading loss in correlation with the number of busbars and their width.

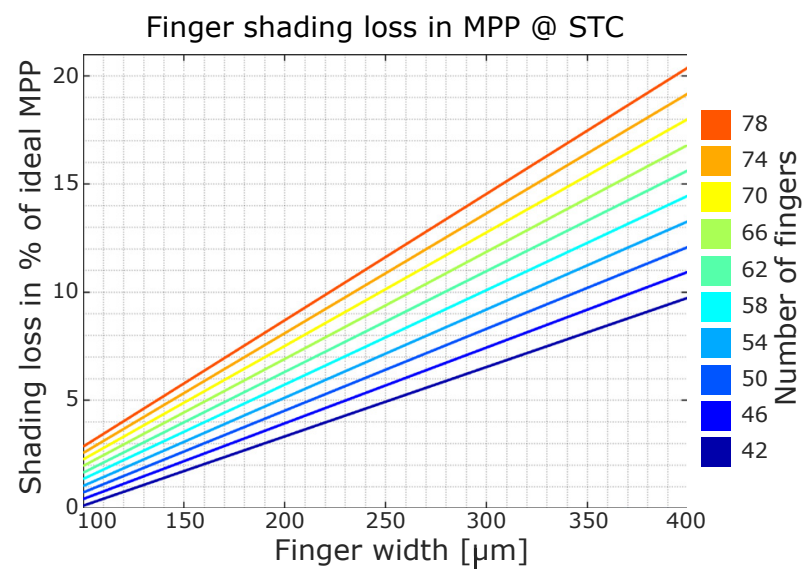

Figure 4: Finger shading loss in correlation with the number of fingers and their width.
Fingers

Finger shading losses are by definition [7] quite similar to the busbar case. The losses $p_{s f}$ are proportional to the ratio of the finger width $\quad W_{F}$ and their spacing $S$. The relation is show in equation and PVMOS simulation results in Fig. 4.

$p_{s f}=\frac{W_{F}}{S}=2 \frac{W_{F} N_{F}}{H_{C}} \propto W_{F} N_{F}$

\subsubsection{Resistive losses}

From intuition resistive losses should decrease with increasing busbar width and with an increasing number

of busbars. Resistive losses $p_{r b}$ are defined according to [7] in equation (4), where $m$ is a factor related to tapering of the busbar (4 for linear tapering and 3 for uniform busbar width).

$p_{r b}=\frac{1}{m} A^{2} B \rho_{b} \frac{J_{M P P}}{V_{M P P}} \frac{1}{W_{B}}=$

$=\frac{1}{m} A^{2} B \rho_{b} \frac{W_{C}}{2} \frac{J_{M P P}}{V_{M P P}} \frac{1}{W_{B} N_{B}} \propto \frac{1}{W_{B} N_{B}}$

As we can see from Fig. 5 resistive losses do indeed decrease with increasing busbar width in a $1 / x$ fashion as it is also evident from equation (4). One can also observe that a decrease in resistive losses is gradually decreasing with an increasing busbar number, which is also in accordance with equation (4).

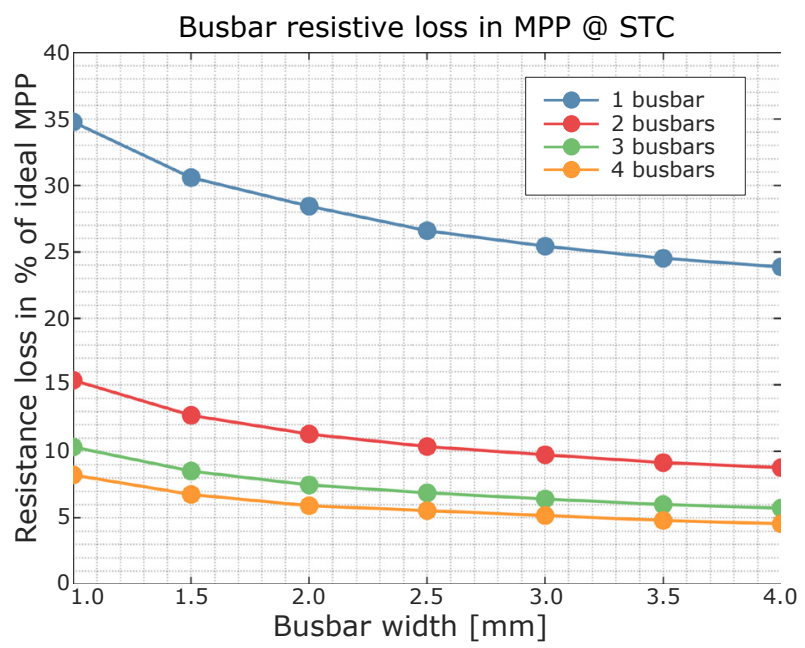

Figure 5: Busbar resistive loss in correlation the number of busbars and their width.

Fingers

Resistive losses due to finger metallisation are actually a combined effect of resistive losses in the top layer of 
the $p-n$ junction due to lateral current flow and actual resistive losses due to current flow along the fingers. Since one depends on the other we have not separated their effect because we cannot directly influence the emitter resistance with the design of the front metallisation. Combined equation for resistive losses due to front contact fingers $p_{r f}$ [7] is therefore given in equation (5). Parameter $m$ relates to the tapering of the fingers in the same fashion as before.

$$
\begin{aligned}
& p_{r f}=\frac{1}{m} B^{2} \rho_{f} \frac{J_{M P P}}{V_{M P P}} \frac{S}{W_{F}}+\frac{\rho_{e}}{12} \frac{J_{M P P}}{V_{M P P}} S^{2}= \\
& =\frac{1}{m} B^{2} \rho_{f} \frac{H_{C}}{2} \frac{J_{M P P}}{V_{M P P}} \frac{1}{N_{F} W_{F}}+\frac{\rho_{e} H_{C}^{2}}{48} \frac{J_{M P P}}{V_{M P P}} \frac{1}{N_{F}^{2}} \propto \\
& \propto K_{1} \frac{1}{W_{F} N_{F}}+K_{2} \frac{1}{N_{F}^{2}}
\end{aligned}
$$

Given the parameters of the cell one could establish which of the two parts will prevail and determine the characteristics of the implied resistive losses. Fig. 6 gives the results of finger resistive loss obtained via PVMOS simulations. The fluctuations seen in the results are probably a consequence of an inappropriate spatial resolution causing a discrepancy between the real and the simulated finger widths. Those points would require a higher resolution for simulation but would result in longer simulation times which were out of scope for this contribution.

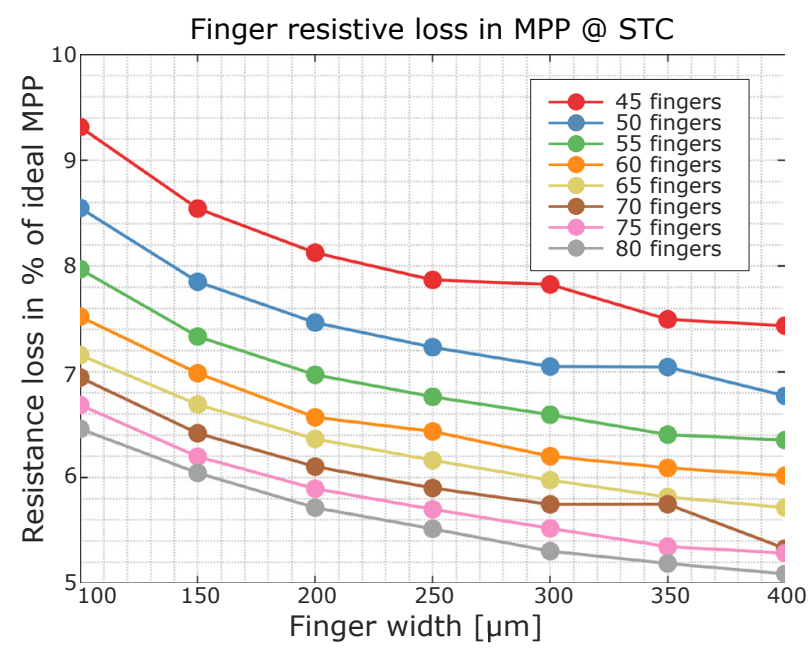

Figure 6: Finger resistive loss in correlation with the number of fingers and their width.

\subsubsection{Combined loss effect}

A solar cell generally exhibits a combination of the aforementioned loss effects. Their interplay is determined by the chosen metallisation geometry. It can be seen from Figs. 7 and 8 that for some chosen parameters there exists an optimal solution or combination of other free parameters minimising the loss. Figs. 7 and 8 respectively show loss change trends with different busbar and finger configurations.

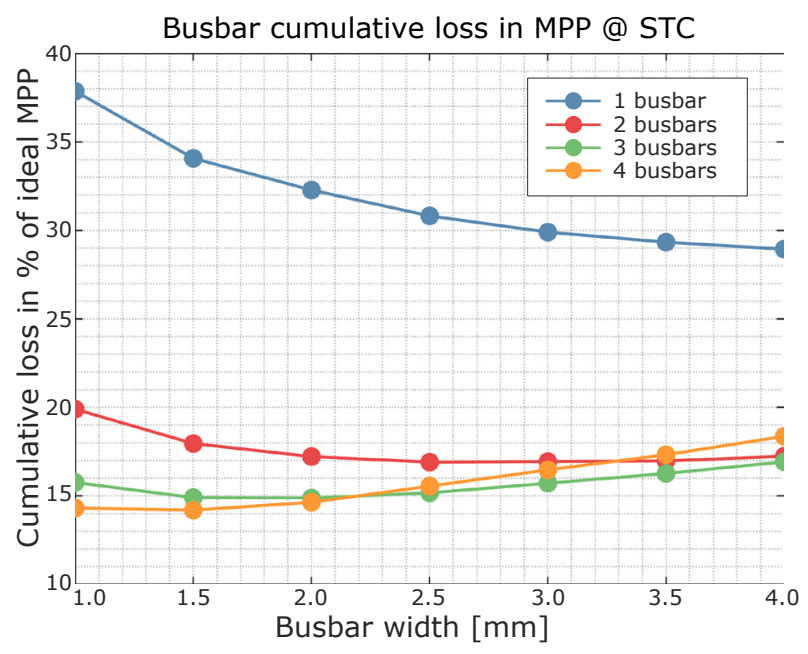

Figure 7: Influence of busbars on the cumulative losses. Number of fingers is fixed to 60 and their width to $100 \mu \mathrm{m}$.

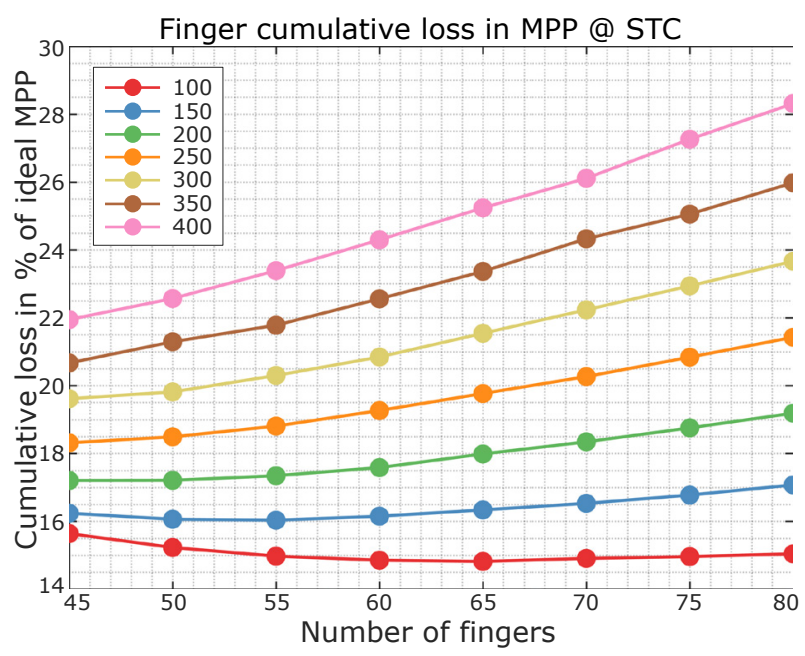

Figure 8: Influence of fingers on the cumulative losses. Number of busbars is fixed to 3 and their width to 2 $\mathrm{mm}$.

\subsection{Optimisation of front metallisation pattern for STC conditions}

Given the results from the previous sections, one could pose a question whether there exists an optimal metallisation geometry, that reduces shading and resistance losses to a minimum. As mentioned before one can only change (given the $\mathrm{H}$-grid metallisation) the metallisation pattern in terms of busbar width $W_{B^{\prime}}$ busbar number $N_{B^{\prime}}$ finger width $W_{F}$ and number of fingers $N_{F}$. We could, if necessary, explore other grid patterns, finger and busbar tapering for shading loss reduction 
and multilevel grid design, but in the scope of this work we have limited ourselves to the most common, basic, busbar-finger H-grid.

We chose to make a sweep of possible different configurations of number of busbars (2-6) and fingers (45-80) under STC conditions. The simulations provided us with a set of I-V curves from which we were able to calculate maximum power points for every configuration as shown in Fig. 9.

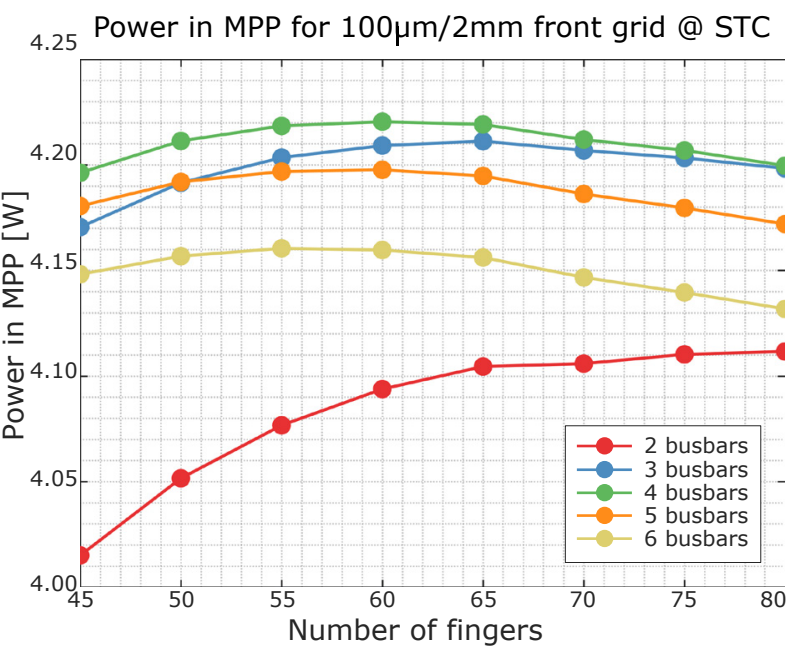

Figure 9: MPP dependence on finger and busbar number for $100 \mu \mathrm{m} / 2 \mathrm{~mm}$ configuration.

We have chosen a configuration with the highest MPP to be the optimal front metallisation grid at STC. With the chosen busbar width $W_{B}$ of $2 \mathrm{~mm}$ and chosen finger width of $100 \mu \mathrm{m}$, the optimal configuration turned out to be 4/60 (busbars/fingers). Since modern technologies allow for finger widths under $100 \mu \mathrm{m}$ we also repeated our simulations at $50 \mu \mathrm{m}$ finger width. The results are shown in Fig. 10.

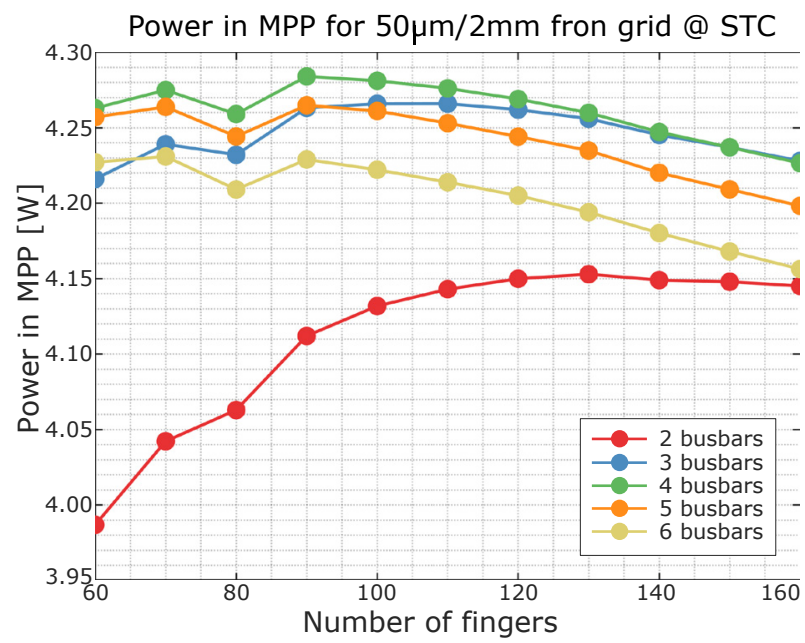

Figure 10: MPP dependence on finger and busbar number for $50 \mu \mathrm{m} / 2 \mathrm{~mm}$ configuration.
One can see, that MPP points follow the same trends as before with broader fingers. The kink at 80 fingers is due to bad resolution of the structuring image. Because of the sampling, a resolution that produced fingers exactly $50 \mu \mathrm{m}$ wide, missed some of the fingers. Increasing the resolution by a small fraction seemed to lessen the error because all fingers were included. But with increasing resolution fingers became narrower than $50 \mu \mathrm{m}$, which is why we think the error is still present. An accurate result would require doubling or tripling the resolution, which we could not afford in the scope of this work. Still we could deduce that the optimum lies somewhere around 90 fingers and 4 busbars for the $50 \mu \mathrm{m}$ fingers.

Fig. 11 shows comparison of $I-V$ and power-voltage curves of both optimal $100 \mathrm{~m} / 2 \mathrm{~mm}$ and $50 \mu \mathrm{m} / 2 \mathrm{~mm}$ configurations. One can observe, that the MPP of the $50 \mu \mathrm{m}$ configuration is slightly higher mostly due to decreased shading and therefore increased short circuit current, which coincides with the fact that between the cases finger width halved while the number of fingers increased by slightly less than a factor of 2 .

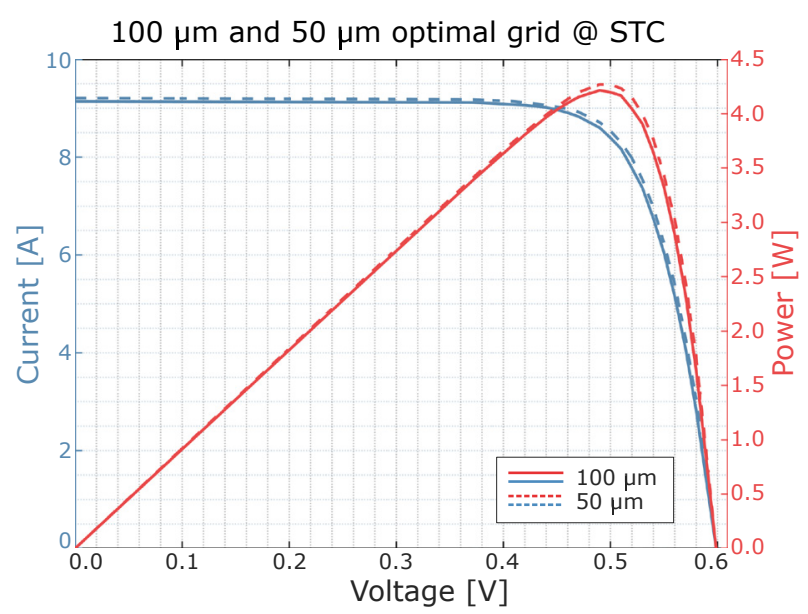

Figure 11: Difference between $I-V$ and $P-V$ curves for optimal $100 \mu \mathrm{m} / 2 \mathrm{~mm}$ and $50 \mu \mathrm{m} / 2 \mathrm{~mm}$ configurations.

Because of the required high resolution for an accurate simulation of $50 \mu \mathrm{m}$ wide fingers and consequentially long simulation times, we could not afford to optimise the energy yield with the $50 \mu \mathrm{m} / 2 \mathrm{~mm}$ grid, since we could not trust the calculation of the MPP at low resolutions. We therefore chose the $100 \mu \mathrm{m} / 2 \mathrm{~mm}$ grid for further calculations.

\subsection{Optimisation of front metallisation for yearly energy yield}

Using the same method, that we have used to optimize the front metallisation for STC, we approached optimi- 
sation for yearly yield. To further reduce the number of possible simulation combinations and decrease simulation time, we have fixed the $W_{B}$ to $2 \mathrm{~mm}$ and $W_{F}$ to 100 $\mu \mathrm{m}$ in the following simulation cases. The same process could be applied to any given grid geometry.

We have chosen three inherently different places for evaluation, since yearly irradiation profiles [8] for Sahara Desert, Ljubljana and Stockholm should vary significantly. Fig. 12 shows annual irradiation (flat oriented surface, direct illumination) vs. irradiation level for all three places.

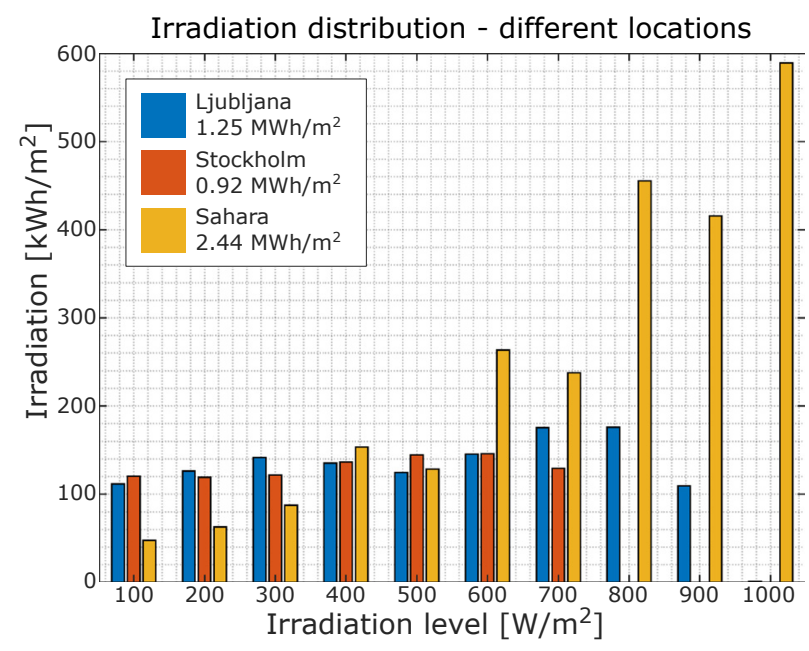

Figure 12: Annual irradiation distribution for Ljubljana, Stockholm and Sahara.

Because annual irradiation peaks lie at different irradiation levels and distinct metallisation patterns perform differently under various irradiation levels, we presumed that there exists a metallisation pattern that would maximise the annual energy yield. The optimal metallisation should favour irradiation level with highest yearly irradiation, but should also provide best allyear-round performance. With respect to that one can assume that the optimal metallisation geometry of for e.g. Sahara Desert should best match the optimal one at STC, since irradiation peak is near $1000 \mathrm{~W} / \mathrm{m}^{2}$.

We performed $I-V$ curve sweeps for different number of busbars and different number of fingers, all at different irradiation levels up to $1000 \mathrm{~W} / \mathrm{m}^{2}$ in $100 \mathrm{~W} / \mathrm{m}^{2}$ steps. From a pool of simulated $I-V$ curves we calculated maximum power points for each geometry and each irradiation level. With the aforementioned data we were able to estimate annual energy yields for each of the selected locations and each metallisation geometry. At each irradiation level, we took into account the efficiency of the metallisation grid and annual irradiation at the selected location, which gave us expected energy yield at each irradiation level. Summation of those partial energy yields gave us an estimate of the annual energy yield. In the end we chose a geometry, that produced the highest annual energy yield. Energy generation profiles are given in Fig. 13, 14 and 15 for each of the locations respectively. By optimising the front metallisation, we were able to increase the annual energy yield by up to approximately $1 \%$ (in the case of Stockholm), for a flat oriented surface and direct illumination.

Sahara $-0.14 \%$ yearly gain

Yearly energy yield for STC and optimal grid

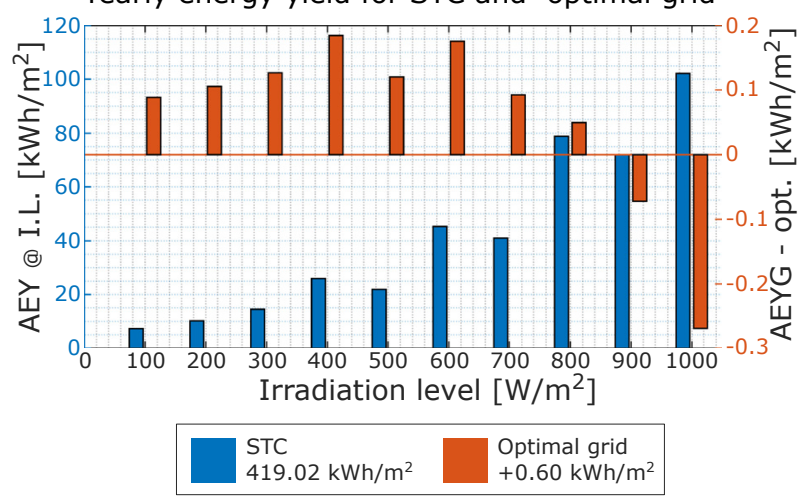

Figure 13: Sahara - Annual energy yield at different irradiation levels for STC optimal grid (blue) and annual irradiation level energy yield gains (AEYG) for an optimal grid (orange).

Ljubljana $-0.63 \%$ yearly gain

Yearly energy yield for STC and optimal grid

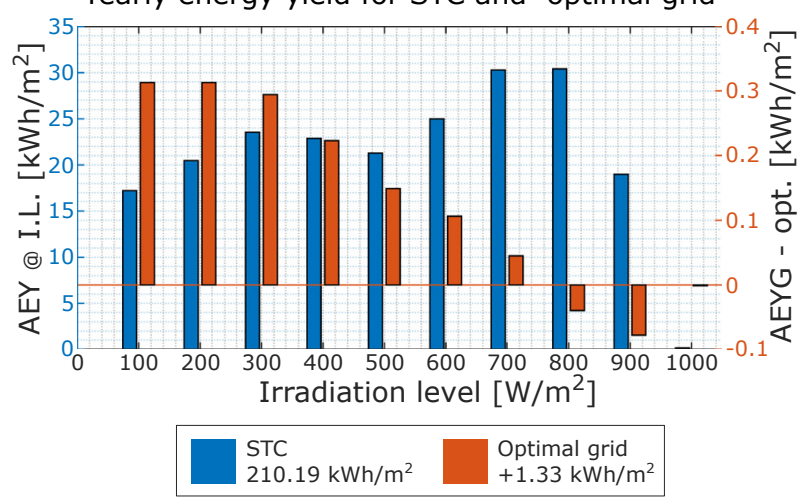

Figure 14: Ljubljana - Annual energy yield at different irradiation levels for STC optimal grid (blue) and annual irradiation level energy yield gains (AEYG) for an optimal grid (orange).

As it can be seen from Fig. 13, 14 and 15 optimal metallisation geometries allow for a performance increase over lower irradiation levels and a slight decrease at higher irradiation levels. Nevertheless, the configuration allows for a greater annual energy yield. Table 1 shows differences between optimal geometries for STC and optimal geometries for annual energy yield (AEY) and effective efficiencies. 
Stockholm - $0.94 \%$ yearly gain Yearly energy yield for STC and optimal grid

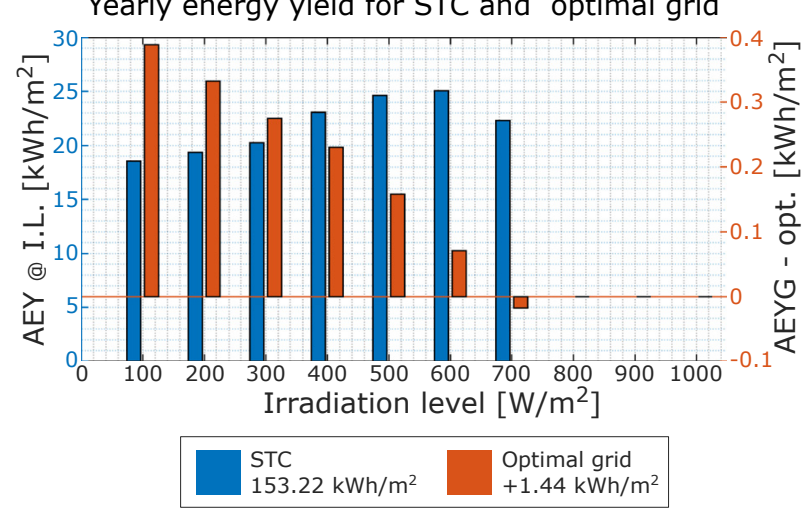

Figure 15: Stockholm - Annual energy yield at different irradiation levels for STC optimal grid (blue) and annual irradiation level energy yield gains (AEYG) for an optimal grid (orange).

If we take yearly irradiation into consideration, we can see, that places with higher annual irradiation or more precisely places with an irradiation peak at higher irradiation levels require a denser front metallisation grid for a better effective efficiency. From a theoretical point of view higher irradiation levels allow for higher optically generated currents, therefore increasing resistive losses and thus requiring front metallisation patters with lower overall resistance, resulting in a higher number of fingers. On the other hand, current densities at lower irradiation levels are substantially smaller therefore resistive losses play a less important role and front metallisation is designed in such fashion that it minimises shading loss, while still providing a low enough resistance for current collection, resulting in a lower overall number of fingers. Shown in Fig. 16 and 17 are shading and resistive losses of optimal metallisation grids for each of the locations at different irradiation levels. It is clearly shown, that higher overall irradiation calls for denser metallisation grids and therefore higher shading loss (e.g. Sahara Desert) and lower overall irradiation needs a metallisation pattern that mitigates shading loss therefore increasing resistive losses (e.g. Stockholm). Ljubljana as a place of average latitude is therefore an average between two extremes with average shading and resistive losses.

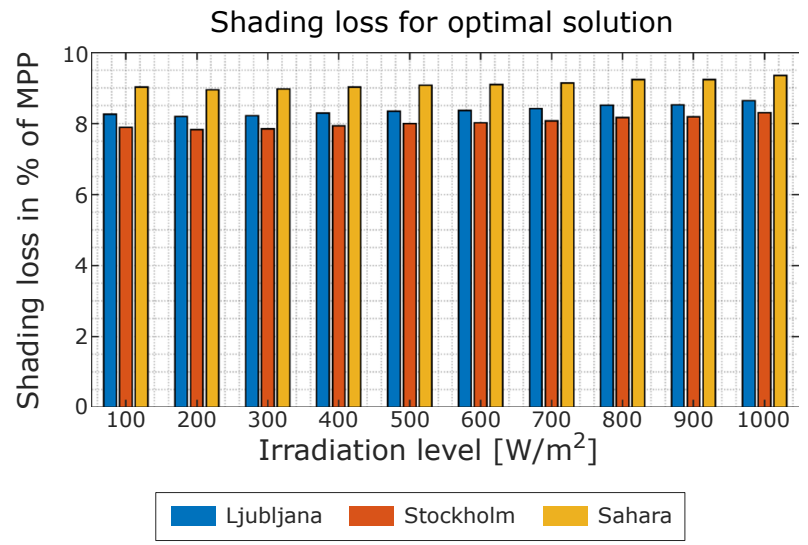

Figure 16: Shading losses at different irradiation levels for an optimal, location specific grid.

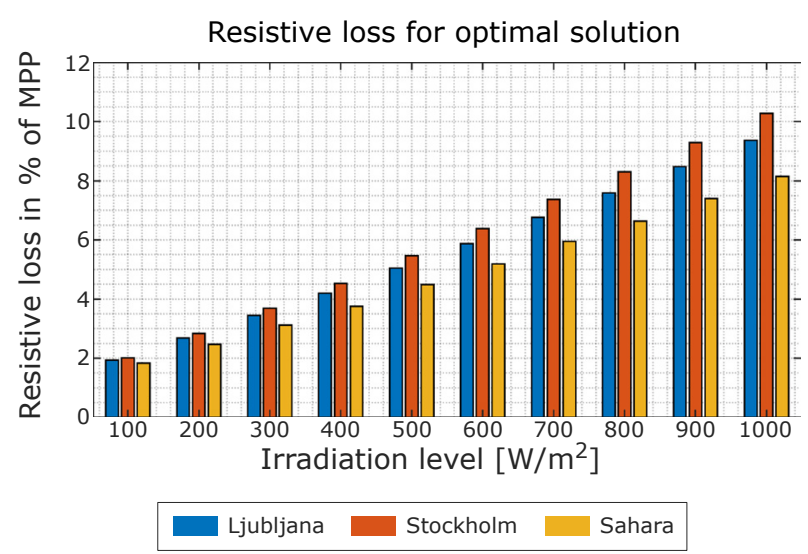

Figure 17: Resistive losses at different irradiation levels for an optimal, location specific grid.

\section{Conclusion}

We have evaluated the effects on losses in MPP due to front metallisation. We have established that for each irradiation level there exists an optimal busbar and finger geometry. With that in mind we have optimised metallisation patterns for either STC or annual energy yield. With the aforementioned optimisation we have achieved an annual energy yield increase of up to $1 \%$ in comparison with STC case.

Table 1: STC and annual energy yield optimised geometry parameters, their expected annual energy yields and effective efficiencies.

\begin{tabular}{|c|c|c|c|c|c|c|c|c|}
\hline & \multicolumn{4}{|c|}{ Optimised for STC } & \multicolumn{4}{|c|}{ Optimised for AEY } \\
\hline & \multirow{2}{*}{$\mathrm{N}_{\mathrm{B}}$} & \multirow{2}{*}{$\mathrm{N}_{\mathrm{F}}$} & AEY & neff & \multirow{2}{*}{$\mathrm{N}_{\mathrm{B}}$} & \multirow{2}{*}{$\mathrm{N}_{\mathrm{F}}$} & AEY & neff \\
\hline & & & {$\left[\mathrm{kWh} / \mathrm{m}^{2}\right]$} & [\%] & & & {$\left[\mathrm{kWh} / \mathrm{m}^{2}\right]$} & [\%] \\
\hline Sahara & 4 & 60 & 419.02 & 17.17 & 3 & 60 & 419.62 & 17.20 \\
\hline Ljubljana & 4 & 60 & 210.19 & 16.82 & 3 & 50 & 211.51 & 16.92 \\
\hline Stockholm & 4 & 60 & 153.22 & 16.65 & 3 & 45 & 154.65 & 16.81 \\
\hline
\end{tabular}


Although our study was limited to only three places, 10 irradiation levels on a horizontal plane and that we have only optimised for finger and busbar numbers, we have still established a workflow with PVMOS as a core component, for an estimation of annual energy yield and its optimisation according to the front metallisation. With an established workflow we could also extend our optimisation to busbar and finger width, more irradiation level bins or different metallisation patterns (e.g. tapered fingers and busbars, other for example "organic" metallisation topologies [9]). The model could also be expanded to include thermal modelling, irradiation at different orientations and inclination angles, and diffuse light therefore providing an extensive tool for annual energy yield estimation.

\section{Acknowledgements}

M. Kikelj acknowledges the Slovenian Research Agency for funding his research activities (program P2-0197), results of which were partially presented in this paper.

\section{Conflict of Interest}

The authors declare no conflict of interest.

The founding sponsors had no role in the design of the study; in the collection, analyses, or interpretation of data; in the writing of the manuscript, and in the decision to publish the results.

\section{References}

1. 'Fraunhofer ISE Photovoltaics Report', Mar. 2019.

2. N. M. Haegel et al., 'Terawatt-scale photovoltaics: Transform global energy', Science, vol. 364, no. 6443, pp. 836-838, may 2019.

https://doi.org/10.1126/science.aaw1845

3. Burgers, A. R., and J. A. Eikelboom., 'Optimizing metallization patterns for yearly yield [solar cell fabrication], Conference Record of the Twenty Sixth IEEE Photovoltaic Specialist conference-1997., IEEE, 1997. https://doi.org/10.1109/PVSC.1997.654068

4. A. R. Burgers, 'How to design optimal metallization patterns for solar cells.', Progress in Photovoltaics: Research and applications, 7.6, pp. 457-461, 1999

https://doi.org/10.1002/(SICI) 1099 159X(199911/12)7:6<457::AID-PIP278>3.0.CO;2-U

5. B. E. Pieters, PVMOS [online] Available: https:// github.com/IEK-5.

6. Pieters, Bart E. "A free and open source finite-difference simulation tool for solar modules." 2014
IEEE 40th Photovoltaic Specialist Conference (PVSC). IEEE, 2014.

https://doi.org/10.1109/PVSC.2014.6925173

7. Green, Martin A. "Solar cells: operating principles, technology, and system applications." Englewood Cliffs, NJ, Prentice-Hall, Inc., 1982. 288 p. (1982).

8. PVGIS [online] Available: http://re.jrc.ec.europa. eu/pvg_tools/en/tools.html

9. Gupta, Deepak K., et al. “Optimizing front metalliation patterns: Efficiency with aesthetics in freeform solar cells." Renewable energy 86 (2016): 1332-1339.

https://doi.org/10.1016/j.renene.2015.09.071

10. Topič, Marko, Kristijan Brecl, and James Sites. "Effective efficiency of PV modules under field conditions." Progress in Photovoltaics: Research and Applications 15.1 (2007): 19-26. https://doi.org/10.1002/pip.717

\section{Appendix}

\begin{tabular}{|c|c|}
\hline Symbol & Explanation \\
\hline $\mathrm{R}_{\mathrm{f}}$ & Fingers' sheet resistance \\
\hline $\mathrm{R}_{\mathrm{e}}$ & Emitter's sheet resistance \\
\hline D1,2 & First and second diode \\
\hline $\mathrm{R}_{\mathrm{b}}$ & Structured sheet resistance of the bulk \\
\hline$p$ & Fractional power loss \\
\hline$P_{\text {loss }}$ & Absolute power loss \\
\hline $\mathrm{P}_{\mathrm{MPP}}$ & Power in the MPP \\
\hline$P_{\text {ideal }}$ & Power of an ideal unshaded cell \\
\hline $\mathrm{P}_{\text {lossy }}$ & Power of the lossy cell \\
\hline $\mathrm{p}_{\mathrm{sb}}$ & Fractional busbar shading power loss \\
\hline $\mathrm{p}_{\mathrm{sf}}$ & Fractional finger shading power loss \\
\hline $\mathrm{p}_{\mathrm{rb}}$ & Fractional busbar resistive power loss \\
\hline$p_{\text {rf }}$ & Fractional finger resistive power loss \\
\hline $\mathrm{W}_{\mathrm{c}}$ & Width of the cell \\
\hline $\mathrm{H}_{\mathrm{c}}$ & Height of the cell \\
\hline$W_{B}$ & Width of the busbars \\
\hline $\mathrm{N}_{\mathrm{B}}$ & Number of busbars \\
\hline A & Same as height of the cell in this case \\
\hline$B$ & Half the spacing between busbars \\
\hline $\mathrm{W}_{\mathrm{F}}$ & Width of the fingers \\
\hline $\mathrm{N}_{\mathrm{F}}$ & Number of fingers \\
\hline $\mathrm{S}$ & Spacing of fingers \\
\hline $\mathrm{m}$ & Tapering factor \\
\hline$\rho_{b}$ & Resistance of the busbars \\
\hline$\rho_{\mathrm{f}}$ & Resistance of the fingers \\
\hline$J_{M P P}$ & Current density in MPP \\
\hline $\mathrm{V}_{\mathrm{MPP}}$ & Voltage in MPP \\
\hline
\end{tabular}



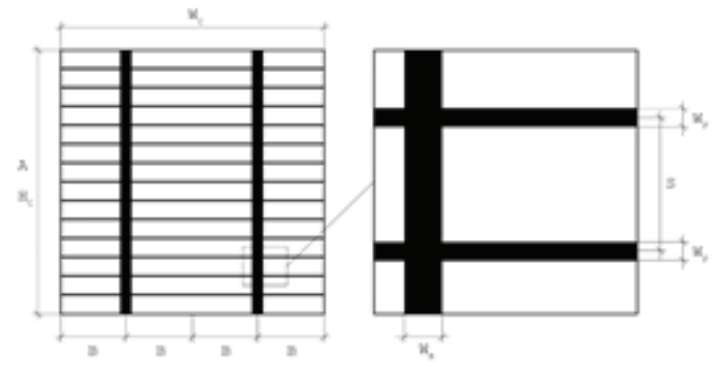

Figure: Definitions of cell's physical dimensions.

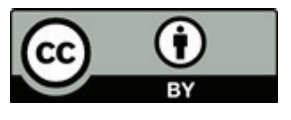

Copyright $\odot 2020$ by the Authors. This is an open access article distributed under the Creative Commons Attribution (CC BY) License (https://creativecommons.org/licenses/by/4.0/), which permits unrestricted use, distribution, and reproduction in any medium, provided the original work is properly cited.

Arrived: 19. 11. 2019

Accepted: 31.01 .2020 